\title{
PEWARISAN TARI RAWAS DALAM MASYARAKAT SUKU SERAWAI DI KAWASAN MANNA, KABUPATEN BENGKULU SELATAN
}

\author{
Fresti Yuliza \\ Program Studi Bina Wisata Akademi Pariwisata Paramitha Bukittinggi \\ Email: frestiyuliza77@gmail.com, HP. 082283428077
}

\begin{abstract}
This paper discusses the rawas dance, which is the name of a dance that lives and develops in the Serawai ethnic community in Manna, South Bengkulu Regency. Applying a qualitative research approach with descriptive analysis methods, a review of the rawas dance is conducted to see: (2) the structure of the dance; (2) the rituals that follow; and (3) the creation myth behind it. Research shows that the rawas dance is sacred by the Manna community, because it is believed to be a dance created by a mystical force. The connection with this mystical power creates a myth about the creation of the rawas dance, which describes the process of creating this dance. The inheritance of the rawas dance then goes along with the inheritance of the myths about its creation. A form of inheritance, traditionally running from one generation to the next through a unique way of learning.
\end{abstract}

Keywords: rawas dance, Serawai, myth, Menjambar ritual, dance inheritance

\begin{abstract}
ABSTRAK
Tulisan ini membahas tentang tari rawas, yang merupakan nama salah satu tarian yang hidup dan berkembang dalam masyarakat suku Serawai di Manna, Kabupaten Bengkulu Selatan. Menerapkan pendekatan penelitian kualitatif dengan metode analisis deskriptif, tinjauan terhadap tari rawas dilakukan untuk melihat: (2) struktur tarinya; (2) ritual yang mengikutinya; serta (3) mitos penciptaan yang melatar belakanginya. Penelitian menunjukkan bahwa tari rawas disakralkan oleh masyarakat Manna, karena diyakini merupakan sebuah tarian yang diciptakan oleh suatu kekuatan mistis. Kaitan dengan kekuatan mistis ini menciptakan suatu mitos tentang penciptaan tari rawas, yang menggambarkan proses penciptaan tari ini. Pewarisan tari rawas kemudian berjalan bersama dengan pewarisan akan mitos tentang penciptaannya itu. Suatu bentuk pewarisan, berjalan secara tradisional dari satu generasi ke generasi berikutnya melalui satu cara pembelajaran yang khas.
\end{abstract}

Kata Kunci: tari rawas, Serawai, Mitos, Pewarisan Tari 


\section{PENDAHULUAN}

Tari rawas merupakan nama salah satu tarian yang hidup dan berkembang dalam masyarakat Manna, Kabupaten Bengkulu Selatan. Setiap gadis yang akan menarikan tari ini diharuskan untuk suci lahir dan batin. Pasalnya, tari rawas, disakralkan oleh masyarakat Manna, karena diyakini merupakan sebuah tarian yang diciptakan oleh suatu kekuatan mistis. Kaitan dengan kekuatan mistis ini menciptakan suatu mitos tentang penciptaan tari rawas, yang menggambarkan proses penciptaan tari ini.

Pewarisan tari rawas kemudian berjalan bersama dengan pewarisan akan mitos tentang penciptaannya itu. Suatu bentuk pewarisan yang berjalan secara tradisional dari satu generasi ke generasi berikutnya melalui satu cara pembelajaran yang khas. Kekhasan proses pewarisan tersebut terletak pada keharusan untuk melaksanakan suatu ritual yang dinamakan dengan menjambar, suatu cara memberikan sesajian kepada roh-roh dan dewadewa untuk meminta izin dalam mempelajari dan menarikan tari rawas.

Pada proses awal dan akhir pembelajaran, para calon penari tari rawas diharuskan mengikuti kegiatan ritual menjambar ini. Keharusan itu terjadi karena para pendukung tari rawas menganggap hasil pembelajaran tersebut tidak akan berhasil dengan baik tanpa melalui ritual menjambar. Oleh sebab itu pula, seiring dengan proses pembelajaran tari rawas, ritual menjambar dipertahankan hingga saat ini oleh masyarakat pendukungnya.

Fenomena mitos yang menyertai tari rawas ini menarik untuk diteliti lebih jauh. Pasalnya, transmisi dan eksistensi tari rawas pada dasarnya tak bisa dilepaskan dengan mitos dan ritual menjambar yang menyertainya. Menarik untuk menelisik lebih jauh tentang peran mitos penciptaan tari rawas serta ritual menjambar dalam proses pewarisan tari ini secara umum. Secara lebih khusus, peran tersebut dilihat dalam konteks pembelajaran tari rawas di mana mitos penciptaan tari rawas dan ritual menjambar berkait erat dengan eksistensi tari rawas pada masyarakat Manna, Bengkulu Selatan.

Sebagai mana layaknya sebuah tari, tari rawas memiliki dimensi tekstual. Namun dalam kasus tari rawas, kajian atas teks tari itu sendiri, tidak dapat dilepaskan dari konteksnya, yakni kepercayaan pendukung tari ini atas suatu mitos, lebih tepatnya mitos penciptaan tari tersebut. Karena itu, penelitian ini bermaksud menyentuh kedua hal itu sekaligus, meskipun baru sebagian kecil saja dari teks dan konteks tari tersebut. Pasalnya, hingga kini belum ada penelitian yang dilakukan terhadap tari rawas, baik dari perspektif kontekstual maupun yang menyentuh dimensi tekstualnya. Sehingga kajian ini, dapat dipandang sebagai suatu studi pendahuluan.

Padahal, penelitian tentang tari rawas baik secara tekstual maupun kontekstual serupa itu akan sangat bermanfaat dikemudian hari sebagai bentuk dokumentasi tertulis yang bisa diajarkan kepada masyarakat seni secara umum dan masyarakat suku bangsa Serawai di Manna, Bengkulu Selatan khususnya. Apalagi mengingat bahwa tari rawas dalam versinya sebagai tari tradisional saat ini semakin terpinggirkan, semakin jarang 
dipentaskan dan bukan tidak mungkin segera akan musnah. Dokumentasi tertulis tersebut tentunya akan menjadi suatu antisipasi yang sangat bermanfaat di kemudian hari, baik sebagai suatu ingatan kolektif maupun sebagai suatu bahan pembelajaran.

\section{METODE PENELITIAN}

Kajian ini dilakukan dengan metode penelitian kualitatif, dengan pendekatan analisis deskriptif. Pengumpulan data yang berkaitan dengan objek penelitian tari rawas ini, dilakukan empat tahapan, yaitu: Studi kepustakaan dilakukan untuk mendapatkan berbagai referensi yang dipandang relevan dengan pengetahuan tentang budaya masyarakat Manna secara umum, dan masalah mitos pada pembelajaran tari rawas secara khusus. Sejauh yang dapat peneliti temukan, dari bukubuku, skripsi, dan jurnal, belum ada pembahasan khusus tentang konsepkonsep yang bisa dijadikan landasan untuk mengkaji perkara serupa ini.

Studi lapangan kemudian dilakukan dengan dua tekhnik pengumpulan data, yakni pengamatan dan wawancara. Wawancara dilakukan terhadap para pelaku dan juga pemuka masyarakat yang terlibat dengan tari rawas. Wawancara berencana dengan kisi-kisi pertanyaan yang telah dipersiapkan terlebih dahulu dilakukan terhadap informan utama yang telah dipilih, yaitu seniman pelaku tari rawas. Selain itu juga melakukan wawancara tak berencana dengan pertanyaan yang bersifat spontan terhadap masyarakat di Manna yang melihat pembelajaran tari rawas.
Sementara pengamatan langsung dilakukan atas pelaksanaan penampilan tari rawas dan ritual menjambar. Selama proses observasi, dilakukan pula proses perekaman baik dalam bentuk audio maupun video. Data yang didapatkan kemudian digunakan untuk menguraikan tentang struktur tari rawas, mitos penciptaannya, dan hubungan antara keduanya dalam konteks pewarisan tari rawas. Adapun metode analisis data yang digunakan ialah metode induksi yaitu, menyimpulkan hal-hal umum yang berkenaan dengan tari rawas berdasarkan data-data khusus yang diperoleh di lapangan.

\section{HASIL DAN PEMBAHASAN}

\subsection{Eksistensi Tari Rawas dalam Budaya Serawai di Manna}

Tari rawas adalah sebuah tari tradisional yang terdapat di Desa Padang Pematang, kecamatan Kota Manna, Bengkulu Selatan. Bengkulu Selatan sendiri merupakan salah satu kabupaten yang berada di bagian selatan Provinsi Bengkulu. Kabupaten ini terdiri atas 11 kecamatan, dengan 136 desa dan kelurahan. Daerah ini dihuni oleh penduduk asli dari suku bangsa Serawai dan Pasemah, yang hidup berdampingan dengan suku bangsa perantau antara lain Jawa, Minangkabau, Melayu, Sunda, Batak, Tionghoa, dan suku bangsa lainnya. Dari komposisi itu, suku bangsa Serawai adalah yang terbesar dari segi jumlah.

Masyarakat Bengkulu Selatan secara umum bekerja pada sektor pertanian, khususnya perkebunan yang menghasilkan beberapa jenis tanaman utama seperti kelapa sawit, kopi, karet, coklat, dan kelapa. Selain di 
sektor pertanian, sebagian kecil masyarakat Bengkulu Selatan juga bekerja pada sektor lain seperti peternakan, perikanan, kehutanan, perindustrian, pertambangan, perdagangan, dan sebagian kecilnya menjadi Pegawai Negeri Sipil.

Penduduk yang ada di Manna, Bengkulu Selatan pada umumnya memeluk agama Islam. Adapun penduduk yang beragama lain jumlahnya hanya beberapa persen saja, yakni Protestan, Katolik, Hindu, dan Budha. Menurut sejarahnya, suku bangsa Serawai di masa lalu memiliki kepercayaan kepada dewa-dewa, yang kemungkinan besar adalah peninggalan agama Hindi, sementara suku Melayu sudah lebih dahulu memeluk agama Islam. Namun di masa kini, mayoritas masyarakat Serawai telah memeluk agama Islam.

Pada abad ke XII hingga XVII di daerah Bengkulu Selatan terdapat dua kerajaan kecil, yaitu Gedung Agung dan Manau Riang. Sampai pada akhir abad ke XV kerajaan-kerajaan kecil ini di bawah pengaruh kerajaan Majapahit yang mengalahkan Sriwijaya pada abad ke XIII. dalam periode ini ratarata kerajaan kecil di daerah Bengkulu di pimpin oleh Bikaw yang merupakan sebutan pimpinan agama Budha. Kemungkinan besar agama ini masuk melalui kekuasaan kerajaan Sriwijaya. Setelah Majapahit mundur pada pertengahan abad XVI agama Islam masuk melalui pengaruh kesultanan Banten. Sejak saat itu Islam berkembang di Bengkulu secara umum, termasuk di Bengkulu Selatan. Perkembangan agama Islam semakin pesat melalui hubungan dagang dengan kerajaan Aceh pada abad XVII.

Kabupaten Bengkulu Selatan oleh sebagian orang juga dikenal dengan sebutan Serawai. Asal nama Serawai dikaitkan dengan dua pendapat yaitu: pertama, pendapat yang mengatakan bahwa Serawai berasal kata 'sauai,' yang maksudnya cabang dua buah sungai yaitu sungai Musi dan sungai Seluma yang dibatasi oleh Bukit Capang. Kedua, pendapat yang mengatakan bahwa Serawai berasal kata dari 'seran' yang artinya celaka (celako). Ini dihubungkan dengan suatu legenda di mana seorang anak raja dari hulu karena menderita penyakit menular lalu dibuang (dihanyutkan) ke sungai dan terdampar. Tempat di mana ia terdampar inilah kemudian kini dikenal sebagai Bengkulu Selatan, di mana sang anak raja kemudian mendirikan sebuah kerajaan yang bernama Kerajaan Serawai (Hasanadi, 2018: 1138).

$\begin{array}{ccc}\text { Kerajaan Serawai } & \text { terpisah } \\ \text { dengan Kerajaan } & \text { Bengkulu }\end{array}$
(Bangkahulu). Kerajaan ini ditemui antara daerah sungai Jenggalu sampai ke muara sungai Bengkenang. Namun kerajaan ini akhirnya terpecah-pecah menjadi kerajaan kecil yang disebut margo (marga). Marga dipimpin oleh seorang datuk dan membawahi beberapa desa atau dusun. Margamarga di Kabupaten Bengkulu Selatan itu masih ada hingga kini, yakni adalah Pasar Manna, VII Pucukan, Anak Lubuk Sirih, Anak Dusun Tinggi, Kedurang, Ulu Manna Ilir, Ulu Manna Ulu, Anak Gumai dan Tanjung Raya. (Hasanadi, 2018: 1138). Namun demikian, kini masyarakat Serawai di Bengkulu Selatan masih bersatu secara kulturak, atas dasar satu keturunan dan satu rumpun bahasa.

Bahasa di Kabupaten Bengkulu Selatan terdiri dari dua bahasa asli yaitu bahasa Serawai dan Bahasa 
Pasemah. Bahasa Pasemah yang banyak dipakai dari muara Sungai Kedurang sampai dengan perbatasan Kabupaten Kaur. Sedangkan Bahasa mayoritas yang digunakan adalah bahasa Serawai yang merupakan turunan dari bahasa Melayu.

Sebagai mana di tempat lain di Nusantara, di Bengkulu Selatan adat adalah sarana dalam mana kebudayaaan dipelihara dan dilestarikan oleh masyarakat setempat. Hal ini dapat kita lihat dari adanya mitos yang masih terpelihara kuat di daerah mereka, dan warisan budaya seperti hukum adat, kesenian adat yang bernuansa religius ataupun upacara adat yang syarat dengan muatan-muatan nasehat dan budi pekerti.

Selain itu, juga masih terdapat praktik-praktik kecil upacara-upacara adat, yang salah satunya adalah ritual ziarah sebagai bentuk penghormatan dan sekaligus ibadah masyarakat terhadap para pendahulunya atau untuk para leluhur dan orang tua. Masyarakat Bengkulu Selatan mempunyai berbagai upacara adat yang memadukan antara yang bernuansa agamis dengan yang sakral, seperti upacara adat Nundang Padi, upacara adat Ziarah, upacara sedekah ritual pengobatan, upacara adat bimbang.

Dalam adat istiadat Bengkulu Selatan terdapat berapa kandungan, seperti hukum adat, kesenian adat, pakaian adat, dan upacara adat. Dalam hal hukum adat, masyarakat Bengkulu Selatan masih sangat memelihara dan melaksanakannya, baik secara tertulis maupun secara lisan. Aturan yang dipedomani secara lisan memang tidaklah ada sangsi nyata berbentuk kesepakatan hukuman. Akan tetapi, bentuk sangsi moral yang lebih menyakitkan biasanya masih diterapkan kepada mereka yang bersalah. Hukuman tersebut bisa saja diberlakukan dalam jangka panjang bagi pelanggar aturan, yang diwujudkan dalam bentuk antara lain dikucilkan, dijauhi orang, dan bicara tidak didengarkan orang. Adapun aturan yang tidak tertulis tersebut, seperti: istinja, petata-petitih, etika, dan norma-norma adat lainnya.

Sebagaimana terpeliharanya adat istiadat, masyarakat Bengkulu Selatan juga masih mempraktikkan berbagai kesenian tradisionalnya, meliputi, kesenian yang bernuansa religius, seperti kaligrafi, tadut, serapal anam. Ada juga kesenian yang merupakan perpaduan antara seni tari, seni musik, dan seni suara seperti, berdendang, tembang, dan lain-lain. Dalam uraianya tentang kearifan lokal suku Serawai di kabupaten Bengkulu Selatan Dihamri (2016: 90) menyebutkan antara pula beberapa tradisi sastra lisan, antara lain Betembang, yakni tradisi melantunkan syair atau pantun diiringi gitar tunggal; dan Andai-Andai yakni tradisi melantunkan kisah seseorang yang termasyur atau kisah jenaka atau pendidikan tanpa iringan.

Sedangkan jenis tarian yang masih terpelihara di Bengkulu Selatan pada dasarnya dapat dibagi dua, yakni: (1) tarian tanpa iringan alat musik seperti, tari bubu, tari pisau dua, tari pedang, dan juga tari silat; dan (2) tarian dengan iringan alat musik, di mana jenisnya yang paling banyak dipraktikkan adalah tari andun, yang tersebar pada setiap kecamatan kecuali di Kecamatan Kedurang. Tari Andun yang artinya adalah kunjungan dalam acara pernikahan, biasanya diselenggarakan dengan acara 
bimbang adat (semacam acara resepsi pernikahan adat). Di masa kini, tari andun bahkan sudah disebarluaskan melalui lembaga pendidikan formal maupun non formal seperti sekolahsekolah dan sanggar-sanggar yang ada di kota Manna, dan diperlombakan dalam berbagai acara (Melisa Wulandari, Kuswarsantyo, 2017: 7)

Sangat berbeda dengan Tari Andun yang masih dipraktikkan secara luas, tari rawas adalah tari tradisional Bengkulu Selatan yang bisa dikatakan hampir punah. Saat ini, tarian ini secara tradisional hanya masih dipraktikkan oleh sekelompok masyarakat yang tinggal di Desa Padang Pematang, kecamatan Kota Manna, Bengkulu Selatan. Uwak Upik, adalah nama salah seorang guru dan penari senior tari rawas di tempat ini. Muridnya tidak lagi banyak jumlahnya. Demikian pula, proses pembelajaran tari rawas itu sendiri sudah semakin jarang dilakukan, seiring terus berkurangnya jumlah murid, dan berkurangnya jumlah kesempatan untuk tampil.

Karena berbagai sebab, tari rawas kini lebih banyak dipraktikkan sebagai sumber penciptaan dari tari Kreasi Baru, seperti salah satunya dipraktikkan oleh Madali Sya'ban, salah seorang koreografer lokal Bengkulu Selatan (Cindhy Pospita Wati, Afifah Asriati, Nerosti, 2018: 7). Salah satu sinyalemen, datang dari budayawan di Manna sendiri, bahwa tari rawas mulai semakin jarang dipraktikkan karena berbagai pihak mulai memandangnya bertentangan dengan ajaran agama Islam yang dianut oleh mayoritas masyarakat Bengkulu Selatan. Hal yang dipandang sangat bertentang itu, adalah kepercayaan tentang adanya kekuatan gaib yang melingkupi tari itu, serta dilaksanakan sebuah ritual dalam pembelajaran tari rawas, yang dinamakan sebagai ritual menjambar.

\subsection{Struktur Tari Rawas dan Mitos Penciptaannya}

Tari rawas yang dalam bahasa Serawai (bahasa sehari-hari Manna) berarti lemah gemulai, lembut dan indah, ditarikan oleh sembilan orang gadis. Menurut kepercayaan masyarakat setempat, setiap gadis yang menarikan tari ini haruslah suci lahir batin, dengan pengertian tidak dalam keadaan menstruasi, tidak sedang mengalami gangguan emosional seperti, marah, sedih, atau kesal. Tarian ini ditarikan oleh para gadis tersebut sambil menyanyikan pantun, yang sekaligus menjadi musik yang mengiringi tarian ini. Sementara itu, pada beberapa bagian tari rawas juga diiringi dengan rebana.

Tari rawas, disakralkan oleh masyarakat Manna karena dianggap diciptakan oleh suatu kekuatan mistis. Menurut mitos, yang diyakini oleh masyarakat Manna, tari rawas diciptakan oleh suatu kekuatan mistis yang bernama Dewa Sembilan. Menurut kisah Uwak Upik (wawancara di Manna, 2 Mei 2008), seorang guru tari rawas, pada masa dahulu kala, ada sembilan orang anak gadis yang belajar dengan "sesuatu" hal yang tidak bisa digambarkan dengan kata-kata, karena bukan manusia. Mereka belajar dengan "sesuatu" itu selama tiga malam, yaitu pada setiap malam ke-14, selama tiga bulan, tanpa adanya guru dalam pengertian manusia. "Sesuatu" yang dikenal dengan nama Dewa Sembilan tersebut, menggerakkan tubuh para gadis tersebut, sehingga membentuk suatu tarian. Dalam proses belajar 
seperti itulah, mereka mendapatkan gerak-gerak tari yang kelak di kemudian hari dinamakan tari rawas.

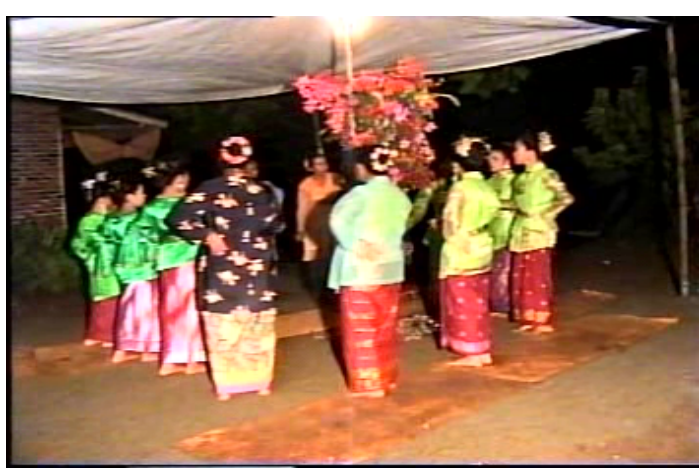

Gambar 1

Para Guru mengajari murid Tari Rawas

(Dokumentasi Fresti Yuliza, 2008)

Sebagai syarat belajar dengan Dewa Sembilan, kesembilan gadis tersebut mengadakan semacam persembahan. Syarat-syarat persembahan inilah yang kemudian menjadi syarat-syarat dalam sebuah ritual yang mengiringi tari rawas hingga sekarang, yang dinamakan dengan ritual menjambar. Adapun syarat-syarat persembahan tersebut di antaranya adalah, nasi kuning yang di atasnya diletakkan daging ayam, karangan bunga 44 macam, uang kertas sebagai uang kemasukan belajar, minyak manis dari kelapa hijau, bulu landak blantan (putih), telur, jeruk nipis, cabe dan garam, tembakau, sirih, dan kemenyan, yang diletakkan dalam sebuah sangkak ayam.

Dewa Sembilan, sang pemilik tari rawas tersebut, dipercayai selalu hadir pada pada pelaksanaan tari rawas (Uwak Upik, wawancara di Manna, 2 Mei 2008). Konon, setelah menyelesaikan proses belajarnya dengan Dewa Sembilan selama tiga bulan, para gadis tersebut mengulangi kembali tari yang dipelajarinya itu di tempat tinggal mereka. Untuk tujuan tersebut mereka menyediakan kembali berbagai persyaratan yang digunakan pada saat mereka belajar dulu. Syaratsyarat itu dikumpulkan dan diletakkan di atas sebuah tiang bambu. Ketika mereka menarikan tarian mengelilingi tiang bambu dan syarat-syarat tersebut, mereka menyaksikan ada seberkas sinar lampu yang mengelilingi mereka. Pada pagi harinya, mereka menyaksikan bahwa pada tiang bambu tempat syarat-syarat itu diletakkan terdapat bekas-bekas kuku, yang mereka percayai adalah bekas jari Dewa Sembilan. Ketika Jambar diturunkan dari tiang bambu, di dalam Jambar mereka juga menemukan tinja dan lima bekas jari Dewa Sembilan.

Demikianlah, mitos tentang kejadian penciptaan tari rawas tersebut diceritakan hingga sekarang. Pada awalnya, mitos tersebut tidak diceritakan kepada para penari yang mempelajarinya. Namun, setelah para penari menyaksikan sendiri adanya cahaya yang mengelilingi mereka pada saat menari, maka mitos tersebut kemudian diceritakan sebagai penjelasan dari kejadian tersebut. Setelah mengetahui kekuatan mistis yang melingkupi tari rawas yang mereka pelajari, biasanya para penari yang belajar semakin termotifasi untuk mempelajarinya (Uwak Upik, wawancara di Manna, 30 September 2008).

Dari proses belajar serupa itulah, mereka mendapatkan gerakgerak tari yang kemudian dinamakan Tari rawas, yang diyakini pernah dipelajari pula oleh sembilan gadis di dalam mitos kepada Dewa Sembilan. Adapun hasil pembelajaran tersebut menghasilkan 11 bagian dalam Tari 
rawas, yang diwariskan hingga sekarang dan masih dapat di saksikan pada masyarakat Manna, yaitu: (1) Sayang Keremak; (2) Sayang Sempayut; (3) Pantun Bersahut; (4) Nanam Percik;

(5) Tari Lampu; (6) Tari Piring Beliku; (7) Tari Piring Alus; (8) Tari Piring Besak; (9) Tari Piring Jarang; (10) Tari Piring Kerap; dan (11) Tari Beremas.

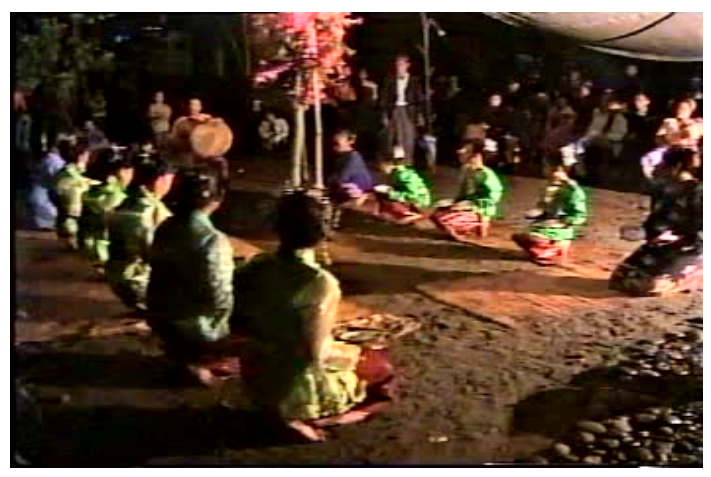

Gambar 2

Formasi Para Penari sambil melantunkan pantun dalam Tari Rawas

(Dokumentasi Fresti Yuliza, 2008)

Sayang Keremak, merupakan nama tarian pembuka dari rangkaian Tari rawas. Pada bagian ini, para penari menari sambil berpantun menyampaikan maksud dan tujuannya, yaitu salam pembuka dan permohonan maaf pada roh-roh terdahulu yang menurunkan tarian ini untuk memulai pelaksanaannya. Salah satu pantun yang dinyanyikan pada bagian ini adalah:

Sayang keremak di pulau lani banyak

Batang kemuning sampiran kain

Minta maaf kami dengan urang banyak

Kami ndak numpang bemain

Rajaulah diutus pulang di padang

Masuk suntri kampung belanda

Tali lah diputus peduman ilang

Kapal dihandam diraja cina
Sayang Sempayut, yang merupakan bagian kedua tari rawas ini tidak jauh berbeda dengan Sayang Keremak. Pantun-pantun yang disampaikan pada bagian ini pun masih mempunyai kemiripan dengan Sayang Keremak dalam hal maksud dan tujuannya. Pantun yang dinyanyikan tersebut, misalnya:

Sayang lah sempayut buah dihutan Limakan kurut batang lah beduri Timpe kan daye karangan tuan Lah sedang lama tidaklah berjumpa

Jai remejai tanggai se lake Ditunde andun kairum dingin Alus mbak budi bujang juare Resap mbak banyu menyuruak bungin

Kapal riam tumbuh di pasir Lah anak cina diam di laut Duduak diam berupa pasir Tidaklah mati sebelum maut

Padang panjang labuhan kepal Tempat militer lah main tenis Sejak hari kemarau petang Duduak lah saya termenung nangis

Pantun Bersahut, demikian nama bagian ketiga dari Tari rawas. Pada bagian ini, para penari berpantun dengan saling bersahut-sahutan. Pantun yang digunakan boleh dibuat sendiri oleh para penarinya. Misalnya seperti:

Dari mana hendak kemana Dari lah kebun ke bandar cina Jangan marah saya bertanya Bunga di laman siapa punya

Malam ini malam senayan 


\section{Malam lah pagi malam selasa Ngapau adinda tidak keruan Bunga di laman kita bersama \\ Tapau lah ke kandis Batan bemasam begulai tunak Tapau lah be anak bilis Batan bemasak lah ikan besak"}

Nanam Percik, yang merupakan bagian ke empat ini menggambarkan keinginan yang besar untuk merubah nasib menuju kehidupan yang lebih layak, hal ini dapat diungkapkan dalam pantun yang disampaikan. Sementara Tari Lampu, adalah bagian ke lima Tari rawas. Pada bagian tari lampu ini, dimana para masing-masing penari dibekali dengan 12 buah piring putih atau di sebut piring belantan yang tipis, yang berfungsi sebagai tempat berinjaknya para penari, serta tiga buah piring sasar untuk tempat lampu. Adapun pantun yang dinyanyikan penari adalah sebagai berikut:

\section{Bunga pandan sehuling dahani Asap kemenyan memanggil dewau Minta tulung di dewau sembilan Minta gimbari tarian lampu Tarian lampu di ujung kuku Batang buluh tengah jerami Kain kuning di belah duau}

Tari Piring Beliku, merupakan nama bagian ke enam, di mana sebelum para penari memulai tariannya di atas piring terlebih dahulu mereka menari di tempat dengan formasi membentuk lingkaran sambil berpantun. Dalam tarian ini ditambahkan alat musik berupa rebana yang di tabuh oleh anggota lainnya jika para penari sudah memulai menari di atas piring.

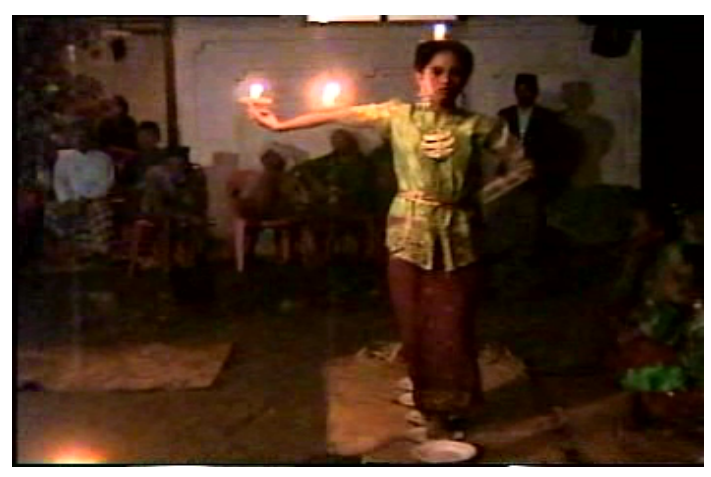

Gambar 3

Seorang Penari Tari Rawas berjalan di atas piring sambil membawa piring dengan lilin menyala

(Dokumentasi Fresti Yuliza, 2008)

Sementara Tari Piring Alus, demikian nama bagian ketujuh, ditarikan dengan terlebih dahuu penari mengambil piring, dan diharuskan menyanyikan pantun. Para penari berhadap-hadapan dengan membentuk barisan bersaf. Pada tari ini piring alus yang digunakan penari diletakkan hanya pada ujung ibu jari di tangan kiri dan kanan.

Tari Piring Besak, merupakan bagian ke delapan, yang mempunyai kemiripan dengan Tari Piring Alus, hanya yang membedakannya pada peralatan yang digunakan, yaitu piringnya agak besar dan ditambah dengan alat musik berupa rebana yang ditabuh oleh anggota penari lainnya.

Tari Piring Jarang, yang merupakan bagian ke Sembilan, mempunyai kemiripan seperti Tari Piring Alus, demikian pula Tari Piring Kerap, yang merupakan bagian ke sepuluh. Bagian yang agak berbeda adalah Tari Beremas, yang meruoakan tarian penutup dari rangkaian Tari rawas. Bagian ini, berisikan pantunpantun yang disampaikan sambil menyanyi sama seperti halnya pada bagian bagian sebelumnya. Pada bagian akhir ini, para penari kembali 
meminta maaf apabila di dalam pelaksanaan tarian ini terdapat kesalahan dan kekurangan.

\subsection{Pewarisan Tari Rawas dan Ritual Menjambar}

Pewarisan tari rawas berjalan bersamaan dengan pewarisan mitos tentang penciptaannya. Proses ini berjalan secara tradisional dari satu generasi ke generasi berikutnya melalui satu cara pembelajaran yang khas. Kekhasan tersebut terletak pada pelaksanaan suatu ritual yang dinamakan dengan menjambar. Menjambar yang dimaksud adalah memberikan sesajian kepada roh-roh dan dewa-dewa untuk meminta izin dalam menarikan Tari rawas.

Sesajian dalam ritual menjambar dinamakan sebagai Jambar, yang terdiri dari berbagai jenis benda, yang masing-masing diyakini memiliki makna dan fungsinya tersendiri, di antaranya: nasi ketan berwarna kuning seekor ayam yang sudah dimasak, dan sebuah sangkak ayam. Di samping itu, pada Jambar juga terdapat syaratsyarat lain yang masing-masing memiliki makna khusus bagi pendukung Tari rawas.

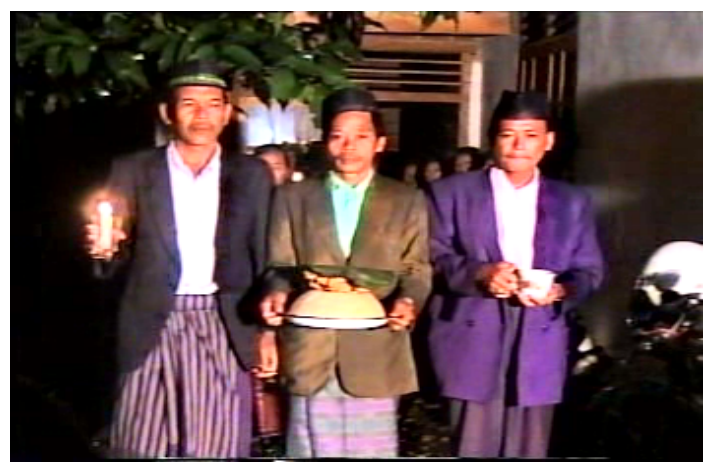

Gambar 4

Kaum Bapak membawa Jambar dalam Ritual Menjambar

(Dokumentasi Fresti Yuliza, 2008)
Pada dasarnya, tari rawas hidup dalam hubungan yang saling mempengaruhi dengan mitos penciptaannya serta ritual menjambar. Menurut Sedyawati (1981: 110) untuk melihat bagaimana kehidupan tari di Indonesia, perlu lebih dahulu dilihat adanya etnik, yang di antara mempunyai perbedaan dalam hal bahasa, adat istiadat dan norma-norma kehidupannya. Tari tumbuh di dalamnya, dalam rangkuman yang erat dari ketiga segi budaya tersebut. Dengan sendirinya perwujudanperwujudan tari etnik berbeda-beda dalam hal bentuk serta landasanlandasan moral maupun mental yang menjadi alasan eksistensinya.

Berdasarkan pendapat tersebut, maka mitos penciptaan tari rawas merupakan landasan mental yang mendasari eksistensi tari tersebut di tengah-tengah kehidupan masyarakat pendukungnya di Manna. Kepercayaan terhadap mitos tari rawas merupakan faktor yang membuat para pendukungnya tetap menghargai tari ini hingga sekarang, dan sekaligus melestarikannya. Proses pelestarian tersebut, diwujudkan dalam bentuk pembelajaran yang dilakukan terusmenerus dari generasi ke generasi.

Di samping itu, mitos penciptaan tari rawas menjadi faktor yang ikut menentukan ketahanan Tari rawas. Dari waktu ke waktu tari rawas tetap terjaga keasliaannya karena tidak seorang pun hingga sekarang melakukan perubahan-perubahan terhadap gerak-geraknya. Padahal, tidak terdapat sangsi atau hukuman baik secara adat maupun sosial yang melarang orang untuk melakukan perubahan terhadap tari pada masyarakat Manna. 
Menurut Uwak Upik (wawancara di Manna, 2 Mei 2008) salah seorang guru dan penari senior Tari rawas, ia tidak keberatan jika ada orang yang melakukan perubahan terhadap tari ini. Akan tetapi ia sendiri enggan melakukannya sebab takut akan mendapatkan bencana atau kemalangan tertentu akibat dari kemarahan empu yang punya tari.

Fenomena ini tampak sesuai dengan yang dinyatakan Junus (1981: 93-94) bahwa mustahil ada kehidupan tanpa mitos. Kita hidup dengan mitosmitos yang membatasi segala tindaktanduk kita. Ketakutan atau keberanian kita terhadap sesuatunya ditentukan oleh mitos-mitos yang kita hidupi. Banyak hal yang sukar untuk dipercayai berlakunya, tapi ternyata berlaku hanya karena penganutnya begitu mempercayai suatu mitos. Dan ketakutan kita akan sesuatu lebih disebabkan karena ketakutan akan suatu mitos, bukan ketakutan akan keadaan yang sebenarnya. Berdasarkan pernyataan itu, maka ketakutan melakukan perubahan terhadap tari rawas oleh masyarakat pendukungnya sendiri merupakan bentuk dari ketakutan terhadap mitos dan bukan ketakutan kepada hal yang sebenarnya.

Hubungan erat antara mitos dengan eksistensi tari rawas tersebut diakui pula oleh berbagai kalangan masyarakat di Manna. Burhanuddin Durhan (Wawancara di Manna, 28 September 2008), salah seorang tokoh masyarakat Manna menginformasikan bahwa terdapat banyak jenis kesenian tradisional Manna yang hilang karena masyarakat pendukungnya tidak lagi percaya kepada mitos. Oleh sebab itu ia juga yakin bahwa tari rawas akan punah jika nanti masyarakat pendukungnya semakin maju sehingga tidak lagi percaya kepada mitos. ${ }^{1}$

Mengenai ritual, Hadi (2000: 2930) mengutip pernyataan Thomas O'Dea, memberikan batasan bahwa: Ritual merupakan suatu bentuk upacara atau perayaan (celebration) yang berhubungan dengan beberapa kepercayaan atau agama dengan ditandai oleh sifat khusus, yang menimbulkan rasa hormat yang luhur dalam arti merupakan suatu pengalaman yang suci.

Menurut Putri (wawancara di Manna, 5 Oktober 2008), keterlibatannya di dalam ritual menjambar memberikan suatu pengalaman yang berharga dan ia merasa memiliki kebanggaan bisa mempelajari Tari rawas. Menurutnya, syarat-syarat pelaksanaan ritual menjambar menunjukkan bahwa tidak sembarang orang bisa terlibat dalam proses pembelajaran Tari rawas. Dengan demikian jelas bahwa mitos penciptaan tari rawas dan pelaksanaan ritual menjambar memiliki peran penting bagi eksistensi tari rawas itu sendiri. Dengan kata lain, tanpa keduanya tari rawas besar kemungkinan akan kehilangan tempatnya dalam dinamika kehidupan masyarakatnya pendukungnya sendiri.

\section{KESIMPULAN}

Berdasarkan pola seperti di atas, mitos mempengaruhi proses pembelajaran Tari rawas. Dengan diceritakan cerita tentang sembilan gadis yang mempelajari tari rawas di

\footnotetext{
${ }^{1}$ Wawancara dengan Armanudin Durhan, di Manna, 28 September 2008
} 
masa lalu, mitos penciptaan tari rawas membangkitkan rasa ketertarikan para pendengarnya, yaitu para gadis yang belajar tari tersebut di masa sekarang. Para gadis tersebut selanjutnya seolaholah diajak untuk mengetahui lebih banyak tentang tari rawas.

Maka dari itu, dapat dipahami bahwa tari rawas itu sendiri dalam proses pembelajarannya pada hakikatnya adalah bagian dari ritual menjambar. Sehingga, keseluruhan ritual ini, pada dasarnya mencontoh urutan peristiwa penciptaan tari rawas, seperti yang dikisahkan dalam mitos.

Dengan demikian jelas bahwa mitos penciptaan tari rawas oleh Dewa Sembilan dan pelaksanaan ritual menjambar memiliki peran penting bagi pewarisan dan eksistensi tari rawas itu sendiri. Dengan kata lain, tanpa adanya mitos Dewa Sembilan yang diwujudkan dalam bentuk ritual menjambar tari rawas besar kemungkinan akan tidak diminati, dan karenanya tidak sakn lagi dipelajari. Lebih jauh, tari rawas dapat kehilangan tempatnya dalam dinamika kehidupan masyarakatnya pendukungnya sendiri.

Menurut Sunardi (2002: 103), mitos berasal dari kata 'muthos,' yang dalam bahasa Yunani berarti cerita. Mitos biasanya adalah cerita sakral yang ditempatkan dalam zaman yang berbeda dengan zaman pencerita, sambil mengungkapkan pemahaman realitas yang menjelaskan beberapa adat kebiasaan dalam masyarakat si pencerita. Berdasarkan teori tersebut, maka cerita tentang penciptaan tari rawas pada dasarnya merupakan suatu mitos, sebab: pertama, cerita tersebut menceritakan kejadian pada masa dahulu kala yang disakralkan oleh para pendukungnya. Kedua, cerita tersebut menjelaskan tentang Tari rawas, yang merupakan satu adat kebiasaan atau tradisi masyarakat setempat.

Jika dilihat dengan cara Junus (1981: 84) yang membagi mitos menjadi dua, yaitu mitos pengukuhan (myth of concern) dan mitos pembebasan (myth of freedom), di mana cerita tradisi rakyat lebih merupakan mitos pengukuhan (myth of concern) yang menguatkan suatu nilai di tengah masyarakat, maka mitos tari rawas pada dasarnya bertujuan untuk mengukuhkan keberadaan tari tersebut di tengah masyarakat pendukungnya. Di sisi lain, sesuai pendapat Pramayoza (2014: 298), selain berfungsi sebagai cara untuk berhubungan dengan masa lalu, mitos penciptaan tari rawas oleh Dewa Sembian juga dapat menguatkan kembali eksistensi dari sebuah kesenian, dalam hal ini tari rawas, yakni dengan cara memberi makna dari masa lalu tersebut di masa kini.

Akhirnya, dapat disimpulkan bahwa mitos tari rawas memiliki kaitan yang erat dengan ritual menjambar, sebuah ritual pada dasarnya berfungsi magi, yaitu usaha manusia untuk berhubungan dengan kekuatan mistis. Sebagaimana dinyatakan Hadi (2002: 338-339), fungsi sebuah ritual yang berhubungan dengan kepercayaan tertentu, dan telah berlangsung cukup lama, ialah sebagai bukti dari kepercayaan terhadap mitos. Dengan demikian, maka ritual menjambar adalah jenis ritus magi, yang di dalamnya mengandung kekuatan yang menghubungkan kehendak manusia dengan penguasanya, roh nenek moyangnya, ataupun menyiasati perjalanan alam, dan mempengaruhi 
kekuatan lainnya (Hadi, 2000: 338339).

Dengan begitu, maka ritual menjambar yang erat kaitannya dengan mitos penciptaan tari rawas oleh Dewa Sembilan, merupakan ritual yang menjadi cara dari pendukung tari rawas untuk berhubungan dengan kekuatan mistis yang dianggap menguasai tari tersebut. Oleh sebab itu, ritual ini merupakan salah satu instrumen penting dari pembelajaran tari rawas, karena dilakukan sebagai cara tradisional dalam menyampaikan mitos Dewa Sembilan, yang ditujukan sebagai perangsang motivasi belajar para gadis yang ingin mempelajari tari rawas.

\section{DAFTAR PUSTAKA}

Armanudin Durhan (60 tahun). Ketua Adat. Wawancara tanggal 28 September 2008 di Manna, Bengkulu Selatan.

Dihamri. (2016). "Kearifan Lokal Suku Serawai Di Kabupaten Bengkulu Selatan," Jurnal Georafflesia, Vol. 1, No. 2, Desember.

Hadi, Sumandiyo. (2000). Seni dalam Ritual Agama. Yogyakarta: Terawang Pers.

Hasanadi. (2018). "Seni Dendang Bengkulu Selatan," Jurnal Penelitian Sejarah dan Budaya, Vol. 4 No. 2, November.
Junus, Umar. (1981). Mitos dan Komunikasi. Jakarta: Penerbit Sinar Harapan.

Pospita, Cindhy, Wati, Afifah Asriati, Nerosti. (2018). "Biografi Madali Sya'ban Sebagai Tokoh Tari Di Bengkulu Selatan," EJurnal Sendratasik, Vol. 6, No. 2., Seri C., Maret.

Pramayoza, Dede. (2014). "Penampilan Jalan Kepang di Sawahlunto: Sebuah Diskursus Seni Poskolonial," Jurnal Ekspresi Seni, Vol. 16, No. 2, November.

Putri (15 tahun). Penari Tari rawas. Wawancara tanggal 5 Oktober 2008 di Manna, Bengkulu Selatan.

Sedyawati, Edy. (1981). Pertumbuhan Seni Pertunjukan Indonesia. Jakarta: Sinar Harapan

Sunardi, ST. (2002). Semiotika Negativa. Kanal: Yogyakarta.

Uwak Upik (65 tahun). Penari, dan Guru Tari rawas. Wawancara tanggal 2 Mei 2008 di Manna, Bengkulu Selatan.

Wulandari, Melisa, Kuswarsantyo. (2017). "Eksistensi Dan Bentuk Penyajian Tari Andun di Kota Manna Bengkulu Selatan," Mangenjali Jurnal Pendidikan Seni Tari, Vol. 6, No. 5. 